\title{
A NEW SPECIES OF RAPHIOCARPUS (GESNERIACEAE) FROM VIETNAM
}

\section{J. Middleton ${ }^{1}$, Q. B. Nguyễn ${ }^{2}$, H. Đ. Trần ${ }^{3}$ \& J. Leong-Škorničková1}

The new species Raphiocarpus axillaris D.J.Middleton from Tam Đảo National Park in northern Vietnam is described and illustrated.

Keywords. Conservation assessment, Didymocarpoideae, Tam Đảo National Park, Trichosporeae. Received 21 April 2021 Accepted 7 July 2021 Published 25 August 2021

\section{Introduction}

The genus Raphiocarpus Chun in the Gesneriaceae was described by Chun (1946), but the single species was generally included as a species of Didissandra C.B.Clarke until resurrected and the genus more widely defined by Weber \& Burtt (1998). There are currently 14 species distributed in China and Vietnam (Weber, 2004; Zhang et al., 2010; Phuong et al., 2012; Chen et al., 2015). Möller \& Clark (2013) note, however, that further work is needed to establish whether Raphiocarpus is monophyletic. The genus is placed in subfamily Didymocarpoideae, tribe Trichosporeae, subtribe Didymocarpinae by Weber et al. (2020).

There are currently six species of Raphiocarpus recorded from Vietnam: $R$. annamensis (Pellegr.) B.L.Burtt, R. clemensiae (Pellegr.) B.L.Burtt and R. evrardii (Pellegr.) B.L.Burtt from Central Vietnam, and $R$. asper (Drake) B.L.Burtt, R. petelotii (Pellegr.) B.L.Burtt and $R$. tamdaoensis Phuong, Xuyen \& Y.G.Wei from northern Vietnam.

A collection from Vĩnh Phúc Province, Tam Đảo National Park, Nguyễn Quốc Bình et al. VMN-B1494, collected in 2011, is of an undescribed species of Raphiocarpus. It is placed in Raphiocarpus due to the combination of 4 fertile stamens and 2-lobed stigma. Tam Đảo National Park is also the type locality of Raphiocarpus tamdaoensis but is easily distinguishable from that species in its whitish to pale-pink corolla (versus pale yellow in $R$. tamdaoensis) and glabrous ovary (versus densely velutinous in $R$. tamdaoensis). Of the other two northern Vietnam species, it can be distinguished from Raphiocarpus asper in the short axillary inflorescences in the lower leaf axils and leafless stem below these, and the corolla whitish to pale pink (versus long subterminal inflorescences and corolla yellow in $R$. asper), and from $R$. petelotii in the calyx lobes free to base (versus calyx lobes fused into a tube in

\footnotetext{
${ }^{1}$ Herbarium, Singapore Botanic Gardens, National Parks Board, 1 Cluny Road, Singapore 259569. E-mail: david_middleton@nparks.gov.sg.

2 Vietnam National Museum of Nature, Vietnam Academy of Science and Technology, 18 Hoàng Quốc Việt Street, Cầu Giấy, Hà Nội, Vietnam 122300.

${ }^{3}$ Becamex Institute of Research and Development, Becamex IDC Corp., 08, Hùng Vương Street, Hòa Phú Ward, Thủ Dầu Một City, Bình Dương Province, Vietnam.
} 
R. petelotii). Nguyễn Quốc Bình et al. VMN-B1494 can also easily be distinguished from the Chinese and Central Vietnamese species in a number of leaf shape, indumentum, calyx and corolla characters.

\section{Species description}

Raphiocarpus axillaris D.J.Middleton, sp. nov.

Affinities within the genus uncertain but differs from all other species by the combination of densely pubescent stems and leaves, symmetrical leaf bases, short axillary inflorescences, narrowly elliptic and densely pubescent calyx lobes free to the base, whitish to pale-pink corolla, and glabrous ovary. - Type: Vietnam, Vĩnh Phúc Province, Tam Đảo National Park, Tam Đảo 2, 21²8'44.0"N, 105³7'39.6"E, 1044 m, 22 ix 2011, Nguyễn Quốc Bình, Jana Leong-Škorničková, Trần Hữu Đăng VMN-B1494 (holotype SING; isotypes $E, P, P R, V N M N)$ ). Figure 1.

Perennial herb to c.70 cm tall. Stems erect, semidecumbent at base, densely appressed hirsute throughout but slightly glabrescent with age. Leaves opposite, those of a pair more or less equal to rather unequal in size; petioles $1.5-4.5 \mathrm{~cm}$ long, densely appressed hirsute; blades symmetrical, elliptic, 6-16.5 × 3.2-7.8 cm, 1.9-2.6 times as long as wide, base cuneate, apex shortly acuminate, margin entire, appressed hirsute above and beneath, more densely so on venation, 7-9 pairs of secondary veins, eucamptodromous, tertiary venation ramified. Inflorescences arising in the axils of lower leaves and below these in leaf scar axils, 1- or 2-flowered, up to 3 inflorescences arising from a single axil, 5-6 cm long (including flower); all axes with long gland-tipped hairs; peduncle 7-22 mm long; bracts narrowly elliptic, 3-4 mm long, with long gland-tipped hairs; flowers held almost horizontally to slightly pendent; pedicels $7-16 \mathrm{~mm}$ long. Calyx of 5 lobes free to base, lobes $6-7.5 \times$ 1.5-1.9 mm, with long gland-tipped hairs outside, glabrous inside. Corolla whitish to pale pink, infundibuliform, 38-45 mm long, sparsely covered with long gland-tipped hairs outside, glabrous inside, with two prominent ridges ventrally from throat into upper tube, limb 2-lipped; tube 31-35 mm long, the lower 11-13 mm narrower but slightly wider at very base, the upper part widening towards throat; upper lip 2-lobed, 5.5-6.5 mm long, lobes 5.5-6.5 $\times$ 6.5-9.5 mm, sinus 4.5-6 mm deep; lower lip 3-lobed, 15-17.5 mm long, lateral lobes 7-9 $\times$ 8-10 mm, middle lobe 8-10.5 × 5.7-7.5 mm. Stamens 4, in 2 pairs, each pair adnate at their apices, divergent, glabrous, anther thecae confluent; posterior pair inserted at $17.5-19 \mathrm{~mm}$ from corolla base, filaments 10-11 mm long, glabrous, anthers 1-1.2 × 1.4-1.5 mm; anterior pair inserted at c. $17 \mathrm{~mm}$ from corolla base, filaments c. $15 \mathrm{~mm}$ long, glabrous, anthers $1.5-1.9 \times 1.7 \mathrm{~mm}$; staminode 1 , slightly clavate, 3-4 mm long. Disc annular, weakly 5-lobed, 1.5-1.7 mm high. Pistil 22-25 mm long, glabrous throughout; ovary 16-17 mm long; style 5-7 mm long; stigma c. $1 \mathrm{~mm}$, 2-lobed. Fruit green when young, mature fruit unknown. 


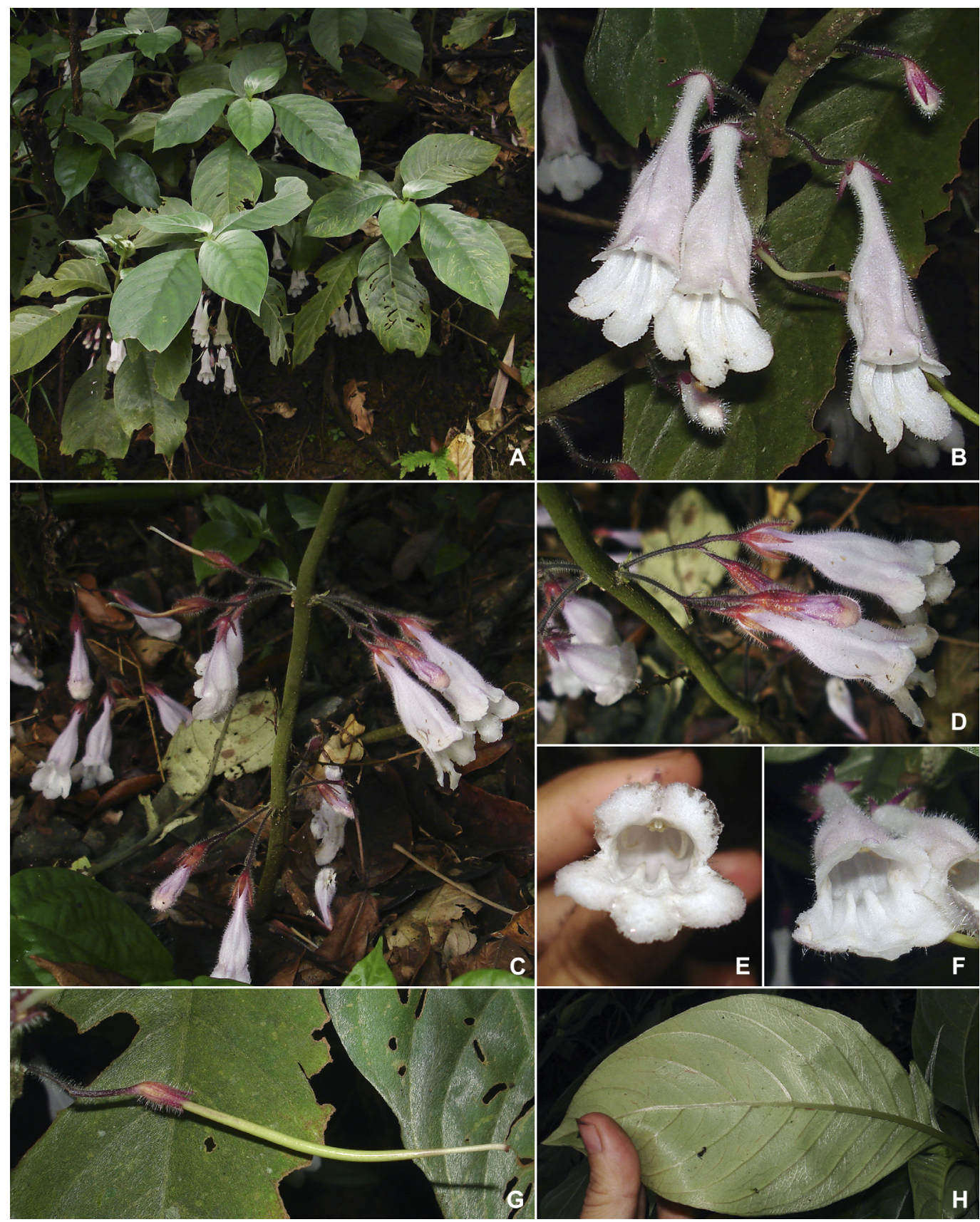

Figure 1. Raphiocarpus axillaris D.J.Middleton, sp. nov. A, Habit; B, flowers; C and D, inflorescences on bare stems; $E$ and $F$, corolla from the front; $G$, very young fruit; $H$, undersurface of leaf. All photographs of the type collection, taken by J. Leong-Škorničková. 
Distribution. Currently known only from Tam Đảo National Park.

Etymology. The epithet axillaris refers to the short axillary inflorescences in this species.

Habitat and ecology. On rocks in montane evergreen broadleaved primary forest, from 1044 to $1101 \mathrm{~m}$.

Conservation status. The species is currently known only from Tam Đảo National Park. As well as the collection from the type location, a second smaller population was seen and photographed along the Máy Giấy trail at $21^{\circ} 26^{\prime} 59.2^{\prime \prime} \mathrm{N}, 105^{\circ} 39^{\prime} 05.9^{\prime \prime} \mathrm{E}$, which is about $4 \mathrm{~km}$ from the type population. Tam Đảo National Park is a legally protected area, but because each population is small enough to be affected by a stochastic event such as a tree fall, we propose a provisional assessment of Vulnerable (VU D2) (IUCN Standards and Petitions Subcommittee, 2019).

\section{Acknowledgements}

We thank the government and local authorities for granting us the necessary permits. We also thank the director of Tam Đảo National Park, Mr Đỗ Đình Tiến, and the field staff for their help during the fieldwork. The research of NQB was supported by the project grant VAST 04.02/20-21. The research of DJM and JL-Š is supported by the National Parks Board, Singapore.

\section{References}

Chen W-H, Chen R-Z, Yu Z-Y, Zhu X-T, Shui Y-M. 2015. Raphiocarpus jinpingensis, a new species of Gesneriaceae in Yunnan, China. Plant Diversity and Resources. 37:727-732.

Chun WY. 1946. Gesneriacearum Plantae Novae Sinicarum. Sunyatsenia. 6(3-4):271-304.

IUCN Standards and Petitions Subcommittee. 2019. Guidelines for Using the IUCN Red List Categories and Criteria, version 14. Prepared by the Standards and Petitions Committee. https://www. iucnredlist.org/resources/redlistguidelines

Möller M, Clark JL. 2013. The state of molecular studies in the family Gesneriaceae: a review. Selbyana. 31(2):95-125.

Phuong VX, Xuyen D-T, Wen F, Wei Y-G. 2012. Raphiocarpus tamdaoensis sp. nov. (Gesneriaceae) from Vietnam. Nordic Journal of Botany. 30(6):696-699.

Weber A. 2004. Gesneriaceae. In: Kubitzki K, Kadereit JW, editors. The Families and Genera of Vascular Plants. Volume VII, Flowering Plants. Dicodyledons. Lamiales (except Acanthaceae including Avicenniaceae). Berlin: Springer, pp. 63-158.

Weber A, Burtt BL. 1998 ['1997']. Didissandra: redefinition and partition of an artificial genus of Gesneriaceae. Beiträge zur Biologie der Pflanzen. 70:153-177.

Weber A, Middleton DJ, Clark JL, Möller M. 2020. Keys to the infrafamilial taxa and genera of Gesneriaceae. Rheedea. 30(1):5-47.

Zhang M-D, Shui Y-M, Chen W-H, Zhang R-M, Li G-Y. 2010. Raphiocarpus maguanensis (Gesneriaceae), a new species from China. Annales Botanici Fennici. 47:71-75. 